\title{
Tables and Diagrams
}

A State Officials

B Onitsha Social Structure

C Abo. Structure of the Umudei Clan

D Oguta Social Structure

E Osomari Social Structure

F Osomari Political Hierarchies

Page

G Stages in Installation Rituals

H Emblems and Regalia

end

of

Book

80

I Succession to the Office of Obi of Onitsha 196

J Succession to the Office of Obi of Abo 214

K Distribution of the Office of Iyase (Onowu) 228

\section{Illustrations}

Map of Iboland

Frontispiece

1 Iyasara Uzoka of Oguta performing the ceremony of Ibe Odu

2 Ngbiligba imi na anya, the bell with human features

3 Iyase Onowu Anatogu of Onitsha

4 Obi Oputa II of Abo

5 Igbudu Ezeukwu: the funeral effigy of the deceased Ezeukwu guarded by acolytes

6 The late Uzoma Ossai II, Ezeukwu of Oguta, the principal kingmaker, with his acolytes

7 Udom Ezeukwu of Oguta

8 Obi Ndokwu Mberekpe of Oguta

Between

pages

126-127

Between

pages

142-143 